Melcior Martínez-Pérez

Francesca Bernabé

Rocío Peña

Rafael Fernández

Avi Nahum

Lluís Blanch

\section{Erratum to: Effects of expiratory tracheal gas insufflation in patients with severe head trauma and acute lung injury}

Published online: 8 November 2011

(C) Copyright jointly held by Springer and ESICM 2011

The online version of the original article can be found under doi:10.1007/s00134-004-2439-6.

M. Martínez-Pérez (®) · F. Bernabé · R. Peña · R. Fernández ·

L. Blanch

Critical Care Center, Hospital de Sabadell,

Corporació Parc Taulí, Institut Universitari Fundació Parc Taulí,

Universitat Autonoma de Barcelona, 08206 Sabadell, Spain

e-mail: Mmartinez@CSPT.es

Tel.: +34-93-7233923

Fax: +34-93-7233863

\section{A. Nahum}

Department of Pulmonary and Critical Care Medicine,

University of Minnesota, Regions Hospital,

St. Paul, Minn., USA

\section{Erratum to: Intensive Care Med (2004) 30:2021-2027} DOI 10.1007/s00134-004-2439-6

The authors' address has been corrected to reflect their affiliation to the Universitat Autonoma de Barcelona. 